\title{
Reducing serum cholesterol levels in women
}

This article was published in the following Dove Press journal:

Neuropsychiatric Disease and Treatment

II September 2012

Number of times this article has been viewed

\section{Roberto Lozano}

Hospital Real Ntra Sra de Gracia, Pharmacy Department, Zaragoza, Spain
Correspondence: Roberto Lozano Hospital Real Ntra Sra de Gracia,

Pharmacy Department,

Ramon y Cajal 60,

50004 Zaragoza, Spain

Email rlozano@salud.aragon.es

\section{Dear editor}

During recent years, statins have been used to reduce serum cholesterol levels, but with conflicting results concerning the benefits obtained in women compared with men in the prevention of cardiovascular events. ${ }^{1}$ Some authors have suggested that the state of inflammation, assessed by the concentration of C-reactive protein (CRP), determines the protective vascular effects of statin therapy. It has been reported that statins might be more beneficial in people with elevated CRP levels, and may be ineffective in people with low concentrations of both CRP and low-density lipoprotein cholesterol. ${ }^{2}$ Furthermore, other authors have reported higher levels of CRP in women than in men. ${ }^{3}$

Gutierrez et $\mathrm{al}^{1}$ observed lower preventive efficacy of statins in women, and Emberson et $\mathrm{al}^{2}$ concluded that the greatest benefit from taking statins is obtained when CRP levels are elevated, which is inconsistent with the fact that women have higher levels of CRP.

At this point, we would like to join the discussion about the importance of both gender and CRP on risk prevention using statins in view of our own experience. On the basis of preliminary data from our 2-year study assessing thromboembolic risk in a small sample of psychiatric patients treated with clozapine, a drug that consistently elevates CRP levels, surprisingly, we found that CRP levels were higher in males than females $(2.9 \pm 1.5 \mathrm{mg} / \mathrm{L}$ versus $1.2 \pm 0.7 \mathrm{mg} / \mathrm{L}$, respectively, $P<0.05$ by $t$-test $)$, contrary to what has been published so far by several investigators. This could explain, according to the conclusions made by Emberson et al, ${ }^{2}$ the observations made by Gutierrez et $\mathrm{al}^{1}$ about the lower preventive effect of statin therapy in women, which would be caused by their lower levels of CRP. Under the influence of agents or circumstances producing an inflammatory-like effect, CRP would be raised to higher levels in males, who would be more likely to benefit from the preventive effect of statins. However, it will be necessary to validate our results in a larger sample.

The purpose of our ongoing research is to quantify the relative risk of thrombovascular events in patients on clozapine using their CRP levels. The study includes 26 outpatients ( $68 \%$ men, $43 \pm 2$ years) who have been on clozapine for at least 2 years. Our experimental data for CRP and prolactin in addition to those from two already published studies ${ }^{4,5}$ have been used to calculate the risk of thrombovascular events.

Mean laboratory values for our patients are as follows: CRP $2.41 \pm 1.6 \mathrm{mg} / \mathrm{L}$, prolactin $523 \pm 537 \mu \mathrm{IU} / \mathrm{mL}$, cortisol $19.7 \pm 7.1 \mu \mathrm{g} / \mathrm{dL}$, thyroid-stimulating hormone 
$2.7 \pm 1.5 \mu \mathrm{UI} / \mathrm{mL}$, thyroxine $1.1 \pm 0.2 \mathrm{ng} / \mathrm{dL}$, cholesterol $197 \pm 46 \mathrm{mg} / \mathrm{dL}$, triglycerides $146 \pm 75 \mathrm{mg} / \mathrm{dL}$, low-density lipoprotein $123 \pm 43 \mathrm{mg} / \mathrm{dL}$, and high-density lipoprotein $50 \pm 16 \mathrm{mg} / \mathrm{dL}$. Mean body mass index was $28.7 \pm 5.6 \mathrm{~kg} / \mathrm{m}^{2}$. On the basis of these results, patients have been grouped according to their overall risk: low risk, CRP $<1$ (19\%); moderate risk, $1<\mathrm{CRP}<3$ (23\%); and high risk, $3<\mathrm{CRP}$ (58\%). The relative risk is 2.1 for cardiovascular events, 1.8 for stroke, and 6.7 for venous thromboembolism. Therefore, patients on clozapine are at higher risk of venous thromboembolism than of cardiovascular disease or stroke, as many authors have suggested.

\section{Disclosure}

The author reports no conflicts of interest in this work.

\section{References}

1. Gutierrez J, Ramirez G, Rundek T, Sacco RL. Statin therapy in the prevention of recurrent cardiovascular events: a sex-based meta-analysis of statin therapy to prevent recurrent CV events. Arch Intern Med. 2012;172(12):909-919.

2. Emberson J, Bennett D, Link E, et al; Heart Protection Study Collaborative Group. C-reactive protein concentration and the vascular benefits of statin therapy: an analysis of 20,536 patients in the Heart Protection Study. Lancet. 2011;377(9764):469-476.

3. Ishii S, Karlamangla AS, Bote M, et al. Gender, obesity and repeated elevation of C-reactive protein: data from the CARDIA cohort. PLoS One. 2012;7(4):e36062.

4. Kaptoge S, Di Angelantonio E, Lowe G, et al; The Emerging Risk Factors Collaboration. C-reactive protein concentration and risk of coronary heart disease, stroke, and mortality: an individual participant meta-analysis. Lancet. 2010;375(9709):132-140.

5. Zacho J, Tybjærg-Hansen A, Nordestgaard BG. C-reactive protein and risk of venous thromboembolism in the general population. Arterioscler Thromb Vasc Biol. 2010;30(8):1672-1678.
Neuropsychiatric Disease and Treatment

\section{Publish your work in this journal}

Neuropsychiatric Disease and Treatment is an international, peerreviewed journal of clinical therapeutics and pharmacology focusing on concise rapid reporting of clinical or pre-clinical studies on a range of neuropsychiatric and neurological disorders. This journal is indexed on PubMed Central, the 'PsycINFO' database and CAS.

\section{Dovepress}

The manuscript management system is completely online and includes a very quick and fair peer-review system, which is all easy to use. Visit http://www.dovepress.com/testimonials.php to read real quotes from published authors. 